\title{
Seroprevalence, Demographic and Blood Donation Characteristics of Blood Donors in the Santa Catarina State, Brazil
}

\author{
Emil Kupek \\ Universidade Federal de Santa Catarina, Brazil
}

Correspondence should be addressed to: Emil Kupek; emil.kupek@ufsc.br

Received Date: 19 March 2014; Accepted Date: 23 May 2014; Published Date: 30 June 2014

Academic Editor: Nelson Tsuno

Copyright @ 2014 Emil Kupek. Distributed under Creative Commons CC-BY 3.0

\begin{abstract}
There is a paucity of publications on regional variations in seroprevalence of infectious diseases in blood donors within Brazilian states, so that suitable time trends can be derived for major demographic groups.
\end{abstract}

A population study of blood donors in the southern state of Santa Catarina, Brazil, was conducted using all computerized records of the blood donors submitted to serologic screening in 2010 . The subjects were predominantly male (57.8\%), aged $18-25$ years $(33.5 \%)$, did not direct their donation to any specific recipient (55.6\%), nor did they provide another blood donation in last 12 months (58.6\%). The highest seroprevalence was observed for the hepatitis B markers (3.0\% for anti-HBc and $0.2 \%$ for $\mathrm{HBsAg}$ ), followed by those for syphilis $(0,08 \%$ VDRL), HIV-1 (0.06\%), hepatitis C (0.05\%), HTLV1/2 $0.01 \%)$ and Chagas disease $(0.01 \%)$. The risk factors associated with higher seroprevalence were associated with the first time donation, being male and of older age. Large regional variations were observed, with the Far West region reaching $7 \%$ of anti-HBc and $0.5 \%$ of HBsAg positive, and the Midwest region showing $0.1 \%$ HIV-positive donors.

Hepatits B markers of both lifetime and recent infection reached a high level among blood donor candidates in Santa Catarina in 2010 and remain the foremost serological deferral criterion, despite some evidence of the reduced transmission rate compared to the beginning of the decade. The seroprevalence of other sexually transmitted infections (HIV, syphilis) also persisted on a level too high for a blood donor population, implying even higher prevalence in the general population.

Keywords: Seroprevalence; blood donor; risk factors; Brazil.

\section{Introduction}

The importance of blood donor screening rests not only on its immediate objective to prevent transfusion-transmitted diseases but also on the epidemiologic data it provides for the geographic regions where the donors come from. Although such data do not represent the general population prevalence, they likely serve as its lower bound estimate, given the fact that clinical examination and pre-donation interview screen out many blood donors with infectious diseases' signs and symptoms, including risky sexual behavior. Consequently, the donors submitted to 
serological testing are healthier than the average individual drawn from the general population and likely to have lower prevalence compared to the latter, according to Andrade et al. (1989). Various countries with advanced epidemiological surveillance such as USA (Glynn et al., 2004) and Germany (Jilg et al., 2001) systematically use blood donor seroprevalence in this way.

In Brazil, similar strategy has been advocated long time ago by Andrade et al. (1989) but it has not been embraced so far, with exception of sporadic research studies. As a result, there is a significant underestimation of prevalence and incidence for many infectious diseases. For example, Brazilian Ministry of Health (2010a) estimated the hepatitis B prevalence at 7.6 per 100.000 inhabitants in 2009 , in contrast with ten to fifty times higher figures based on blood bank seroprevalence found by Kupek (2004), Maresch et al. (2008) and de Almeida Neto et al. (2013). The problem is exacerbated by large regional variation across the country.

This paper deals with seroprevalence of transfusion-transmitted diseases in blood donors in the Brazilian state of Santa Catarina in the year 2010, before a pilot NAT screening was introduced for HIV and hepatitis $C$. The focus here is on viral infections which are major causes of blood donor deferral in serologic screening: hepatitis B, hepatitis C and HIV. Other infections by T. pallidum, HTLV and T. cruzi are only briefly reported as their contributions to the donor deferral were much smaller for the latter two and the former was described in more details in another paper (Baião et al., 2014). In addition, the study aims to provide a lower bound of the infection prevalence estimates for the general population of the Santa Catarina state in Brazil using the blood donor population data.

\section{Methods}

This was a population study of blood donors submitted to serologic screening in 2010 in the federal state of Santa Catarina,
Brazil, based on their computerized records. The records are centralized in the state capital Florianópolis and cover over $95 \%$ of the blood supply in the state. The information on age, sex, residence location, previous donations within 12 months, directing the donation to a specific recipient and serologic test results were extracted and analyzed. Those without complete information on residence were treated as a separate category, whereas all other donors were classified into one of the following regions: Southern ("Sul"), Greater Florianópolis, ("Grande Florianópolis"), Mountain Highland ("Planalto Serrano"), Northern/Northeastern Highland ("Planalto Norte/Nordeste"), Far West ("Extremo Oeste"), Midwest ("Meio Oeste") and the Itajaí Valley ("Vale/Foz do Itajaí"). Serological markers included anti-HBc and HBsAg for hepatis B, anti-HCV for hepatitis C, anti-HIV1/2 (EIA, Western Blot) for HIV, treponemic (FTA-ABS, ELISA) and nontreponemic (VDRL) tests for T. pallidum, anti-HTLV1/2 for HTLV infection and antiT.cruzi for Chagas disease. The laboratory kits and their manufacturers were as following: Prism (Abbott Laboratories, Wiesbaden, Germany) for anti-HIV1,2,0 and anti-HCV, CHIRON RIBA HCV 3.0 SAI (Novartis Vaccines and Diagnostics, Emeryville, CA, USA) for screen-positive anti-HCV, Enzygnost Integral II (Siemens, Marburg, Germany for the fourth generation of anti-HIV Ag/Ab ("combo") VDRL Bras (Laborclin, Pinhais/PR, Brazil), FTA-ABS test (WAMA Diagnostica, São Paulo, Brazil) and the EIA test by Abbott (Abbott Park-II, USA) for syphilis, Hepanostika Anti-HBc Uni-Form (bioMérieux, Geneva, Switzerland) and ORTHO HCV 3.0 ELISA Test System (Ortho Clinical Diagnostics, Raritan, NJ, USA) for hepatitis B serological markers, CHAGATEST ELISA (Wiener, Rosario, Argentina) for anti-T. cruzi and HTLV I/II $\mathrm{Ab}$ Capture Elisa test-ORTHO (Ortho Clinical Diagnostics, Raritan, NJ, USA) for HTLV types I and II. All seven regional blood banks of the Santa Catarina state used the same kits during the period analyzed.

Blood bank screening procedures followed the Brazilian Ministry of Health (2009) 
regulations and guidelines which apply the same routine all over the country except for some small modifications in the areas endemic with malaria. However, the latter are restricted to the Amazon region and far away from the Santa Catarina state. Prior to serological screening, all candidates for blood donation were screened for eventual past impediments in the blood bank computerized records. If no such impediment was found, they underwent medical checks for blood pressure and body temperature. Subsequently, they were interviewed for risky sexual behaviour (having casual sex and/or multiple or same-sex partners or partner diagnosed with a sexually transmitted disease), having been diagnosed with a range of chronic and infectious diseases, as well as for exposure to certain blood-borne diseases abroad. Those who did not present any impediment to accomplish the donation were referred for blood collection. Self-exclusion was offered after the blood collection.

The confirmation rate of screen-positive donors by subsequent serologic tests was applied to those who did not return for the latter procedure in order to reduce the downward bias for seroprevalence which occurs without such correction. The estimates were related to the donor region of residence, age, sex, having donated blood in the last 12 months and directing donation to a specific recipient by means of logistic regression. The $95 \%$ confidence intervals were used to evaluate the parameter variation. Stata statistical software, version 9 (StataCorp 2005), was used for all calculations. Regional variations in seroprevalence were displayed as maps.

The study was approved by the blood bank administration (HEMOSC) and Universidade de Santa Catarina Ethics Committees $(843 / 10)$, in accordance with the Helsinki Declaration.

\section{Results}

Over 82.000 blood donors were submitted to serological testing in Santa Catarina in 2010 , which is about $1.3 \%$ of its population. The percentage varied between $0.41 \%$ in the Midwest region and $1.59 \%$ in the Far West region. Approximately $10 \%$ of the donors did not provide complete residence information due to omitting parts of the zip code.

Men outnumbered women by $30 \%$ (Table 1 ). Most of the donors were between 18 and 35 years of age and did not provide a previous blood donation in the last 12 months, neither did they direct blood donation to a specific recipient.

Table 1. Demographic and Blood Donation Characteristics of Donors Submitted to Serologic Screening in Santa Catarina, 2010.

\begin{tabular}{|l|l|l|}
\hline Donor characteristics & $\mathrm{N}$ & $\%$ \\
\hline Sex $(\mathrm{n}=82.359)$ & & \\
\hline Men & 47611 & 57.8 \\
\hline Women & 34748 & 42.2 \\
\hline Age (n=82.359) & & \\
\hline $18-25$ years & 27635 & 33.5 \\
\hline $26-35$ years & 26930 & 32.7 \\
\hline 36-45 years & 16389 & 19.9 \\
\hline 46+ years & 11405 & 13.8 \\
\hline Type of donation (n=60.886) & & \\
\hline Not directed to specific recipient & 45765 & 75.2 \\
\hline Directed to specific recipient & 15121 & 24.8 \\
\hline Freqüência de doação (n=82.361) & & \\
\hline First time donor & 48301 & 58.6 \\
\hline Repeat donor & 34060 & 41.3 \\
\hline
\end{tabular}


Hepatitis B serological markers were the most prevalent ones, with $3.01 \%$ of anti$\mathrm{HBc}$ and $0.25 \%$ of HBsAg positive test results (Table 2). Other seroprevalences per 100.000 were as following: 81.3 for syphilis, 64.3 for HIV, 54. 6 for hepatitis C, 12.1 for HTLV and 9.7 for the Chagas disease. Male donors had significantly higher prevalence of both hepatitis B serologic markers, as well as that of HIV.

Table 2. Prevalence of Infection Markers by Sex in Blood Donors Submitted to Serologic Screening in Santa Catarina, 2010

\begin{tabular}{|c|c|c|c|c|}
\hline \multirow{3}{*}{$\begin{array}{l}\text { Serologic } \\
\text { markers }\end{array}$} & \multicolumn{2}{|c|}{ Sex } & All & \multirow[t]{3}{*}{$\mathrm{PR}^{\mathrm{b}}$} \\
\hline & Men & Women & $(95 \%$ CI a $)$ & \\
\hline & $(95 \%$ CI a) & $\left(95 \% \mathrm{CI}^{\mathrm{a}}\right)$ & & \\
\hline \multirow[t]{2}{*}{ Anti-HBC } & 3023.6 & 975.4 & 3009.3 & 3.1 \\
\hline & $(2872.5-3182.3)$ & $(878.2-1079.2)$ & $(2893.1-3127.6)$ & $(2.9-3.6)$ \\
\hline \multirow[t]{2}{*}{ HBsAg } & 325.3 & 31.6 & 254.0 & 10.3 \\
\hline & $(276.4-380.9)$ & $(91.5-165.5)$ & $(223.3-294.4)$ & $(8.7-12.0)$ \\
\hline \multirow[t]{2}{*}{ Anti-HCV } & 60.9 & 42.4 & 54.6 & 1.4 \\
\hline & $(40.8-87.5)$ & $(24.2-68.8)$ & (39.9-73.1) & $(0.9-12.0)$ \\
\hline \multirow[t]{2}{*}{ Anti-HIV } & 75.6 & 29.1 & 64.3 & 2.6 \\
\hline & $(53.0-104.7)$ & $(14.5-52.1)$ & $(48.2-84.2)$ & $(1.8-3.6)$ \\
\hline \multirow[t]{2}{*}{ VDRL } & 75.6 & 68.9 & 81.3 & 1.1 \\
\hline & $(53.0-104.7)$ & $(45.0-100.9)$ & $(63.0-103.3)$ & $(0.8-1.5)$ \\
\hline \multirow[t]{2}{*}{ Anti-T.cruzi } & 8.4 & 10.6 & 9.7 & 0.8 \\
\hline & $(2.3-21.5)$ & $(2.9-27.1)$ & $(4.2-19.1)$ & $0.2-1.9)$ \\
\hline \multirow[t]{2}{*}{ HTLV } & 8.4 & 15.9 & 11.6 & 0.5 \\
\hline & $(2.3-21.5)$ & $(5.8-34.6)$ & $(4.2-19.1)$ & $(0.1-1.2)$ \\
\hline
\end{tabular}

a Confidence interval

b Prevalence ratio (women as the reference category)

Older age increased the chances of positive test results for hepatites $\mathrm{B}$ and $\mathrm{C}$ markers (Table 3). Anti-HBc was over five times more frequent among the donors over 45 years of age compared to those aged 18-25 years, whereas HBsAg prevalence more than doubled in comparison with the youngest age group. Hepatitis $\mathrm{C}$ was significantly more likely among the oldest (45-60 years) donors compared to all other age groups.

Table 3. Seroprevalence per 100.000 by Age in Blood Donors in Santa Catarina, 2010

\begin{tabular}{|c|c|c|c|c|c|c|c|}
\hline Serological & \multicolumn{7}{|c|}{ Age groups (95\% confidence intervals) } \\
\hline marker & $18-25$ & $26-35$ & $\mathrm{PR}^{\mathrm{a}}$ & $36-45$ & $\mathrm{PR}^{\mathrm{a}}$ & $46-60$ & $\mathrm{PR}^{\mathrm{a}}$ \\
\hline \multirow{2}{*}{ Anti-HBc } & 1019 & 2764.3 & 2.7 & 4686.1 & 4.6 & 5330.8 & 5.2 \\
\hline & $\begin{array}{l}\text { (902- } \\
1142)\end{array}$ & $(2570-2965)$ & $(2.5-2.9)$ & $\begin{array}{l}(4367- \\
50201)\end{array}$ & $(4.3-4.9)$ & $\begin{array}{c}\text { (4926- } \\
5759)\end{array}$ & $(4.8-5.7)$ \\
\hline \multirow[t]{2}{*}{ HBsAg } & 125.2 & 316.7 & 2.5 & 317.2 & 2.5 & 265.2 & 2.1 \\
\hline & $\begin{array}{l}88.2- \\
176.1) \\
\end{array}$ & $(252.3-390.1)$ & $(2.0-3.1)$ & $\begin{array}{c}(237.0- \\
415.9)\end{array}$ & $(1.9-3.3)$ & $(177-375)$ & $(1.4-3.0)$ \\
\hline \multirow[t]{2}{*}{ Anti-HCV } & 32.6 & 59.4 & 1.8 & 42.7 & 1.3 & 114.0 & 3.5 \\
\hline & $(14.9-61.8)$ & $(33.9-96.5)$ & $(1.0-3.0)$ & $\begin{array}{l}(17.2- \\
88.0)\end{array}$ & $0.5-2.7)$ & $\begin{array}{l}(60.7- \\
194.8)\end{array}$ & $(1.9-6.0)$ \\
\hline \multirow[t]{2}{*}{ Anti-HIV } & 65.1 & 44.5 & 0.7 & 67.1 & 1.0 & 52.6 & 0.8 \\
\hline & $\begin{array}{l}(38.6- \\
102.9) \\
\end{array}$ & $(23.3-77.8)$ & $(0.3-1.2)$ & $\begin{array}{l}(33.5- \\
120.1) \\
\end{array}$ & $(0.5-1.8)$ & $\begin{array}{l}19.3- \\
114.5) \\
\end{array}$ & $(0.3-1.8)$ \\
\hline \multirow[t]{2}{*}{ VDRL } & 43.4 & 70.5 & 1.6 & 103.7 & 2.4 & 122.7 & 2.8 \\
\hline & (22.4-75.8) & $(42.5-101.2)$ & $(1.0-2.5)$ & $\begin{array}{l}(60.4- \\
166.0) \\
\end{array}$ & $(1.4-3.8)$ & $\begin{array}{l}67.1- \\
205.9) \\
\end{array}$ & $(1.4-3.8)$ \\
\hline \multirow[t]{2}{*}{ Anti-T.cruzi } & 0.0 & 7.4 & \multirow[t]{2}{*}{$\bar{b}$} & 24.4 & \multirow[t]{2}{*}{$\mathrm{b}$} & 17.5 & \multirow[t]{2}{*}{$\mathrm{b}$} \\
\hline & $(0.0-0.8)$ & $(0.9-26.8)$ & & $(6.6-62.5)$ & & $(2.1-63.3)$ & \\
\hline \multirow[t]{2}{*}{ Anti-HTLV } & 14.5 & 11.1 & 0.8 & 24.4 & 1.7 & 26.3 & 1.8 \\
\hline & $(3.9-37.1)$ & $(2.3-32.5)$ & $(0.1-2.2)$ & $(6.6-62.5)$ & $(0.5-1.4)$ & $(5.4-76.8)$ & $(0.4-5.3)$ \\
\hline
\end{tabular}

a relative to the 18-25 age group as the reference category

b not applicable 
The donors without previous donation in the last 12 months had between 15 and 33 times more chances to test positive on hepatites B and C markers. (Table 4).
Directing donation to a specific recipient also increased the risk of the positive test result for anti-HBc.

Table 4. Seroprevalence per $\mathbf{1 0 0 . 0 0 0}$ by Type of Blood Donation and Previous Donation Frequency in Blood Donors in Santa Catarina, 2010

\begin{tabular}{|c|c|c|c|c|c|c|}
\hline \multirow[t]{3}{*}{$\begin{array}{c}\text { Serologic } \\
\text { markers }\end{array}$} & \multicolumn{3}{|c|}{$\begin{array}{l}\text { Donation directed to a specific } \\
\text { recipient }\end{array}$} & \multicolumn{3}{|c|}{$\begin{array}{l}\text { Donated blood in last } 12 \\
\text { months }\end{array}$} \\
\hline & Directed & $\begin{array}{c}\text { Not } \\
\text { directed }\end{array}$ & \multirow[t]{2}{*}{$\begin{array}{c}\mathrm{PR} \\
\mathrm{b}\end{array}$} & No & Yes & \multirow[t]{2}{*}{$\overline{P R^{c}}$} \\
\hline & $\left(95 \% \mathrm{CI}^{\mathrm{a}}\right)$ & $\left(95 \% \mathrm{CI}^{\mathrm{a}}\right)$ & & $\left(95 \% \mathrm{CI}^{\mathrm{a}}\right)$ & $\begin{array}{l}\left(\begin{array}{l}95 \% \mathrm{CI} \\
\mathrm{a})\end{array}\right. \\
\end{array}$ & \\
\hline \multirow[t]{2}{*}{ Anti-HBC } & 4909.5 & 3789.0 & \multirow[t]{2}{*}{1.3} & 4896.3 & 150.1 & \multirow[t]{2}{*}{32.6} \\
\hline & $\begin{array}{l}(4568.2- \\
5263.5)\end{array}$ & $\begin{array}{l}(3615.8- \\
3967.9)\end{array}$ & & $\begin{array}{l}(4705.6- \\
5092.6)\end{array}$ & $\begin{array}{c}(111.5- \\
196.8)\end{array}$ & \\
\hline \multirow{2}{*}{$\begin{array}{l}\text { Anti- } \\
\text { HBsAg }\end{array}$} & 350.4 & 346.9 & \multirow[t]{2}{*}{1.0} & 404.4 & 19.7 & \multirow[t]{2}{*}{20.5} \\
\hline & $(262.7-458.2)$ & $\begin{array}{c}(293.6- \\
403.3)\end{array}$ & & $\begin{array}{l}(349.1- \\
464.4)\end{array}$ & $(8.3-42.3)$ & \\
\hline \multirow[t]{2}{*}{ Anti-HCV } & 92.6 & 67.7 & \multirow[t]{2}{*}{1.4} & 89.0 & 5.9 & \multirow[t]{2}{*}{15.1} \\
\hline & $(50.6-155.3)$ & $(46.0-96.1)$ & & $\begin{array}{l}(64.4- \\
120.0)\end{array}$ & $(0.7-21.2)$ & \\
\hline \multirow[t]{2}{*}{ Anti-HIV } & 52.9 & 98.3 & \multirow[t]{2}{*}{0.5} & 62.1 & 49.9 & \multirow[t]{2}{*}{1.2} \\
\hline & $(22.8-104.2)$ & $\begin{array}{l}(71.7- \\
131.5)\end{array}$ & & $(41.9-88.6)$ & $\begin{array}{l}(29.1- \\
79.9)\end{array}$ & \\
\hline \multirow[t]{2}{*}{ VDRL } & 132.3 & 102.7 & \multirow[t]{2}{*}{1.3} & 95.2 & 47.0 & \multirow[t]{2}{*}{2.0} \\
\hline & $(80.8-204.2)$ & $\begin{array}{l}(75.5- \\
136.5)\end{array}$ & & $\begin{array}{l}(69.7- \\
127.0)\end{array}$ & $\begin{array}{l}(26.8- \\
76.3)\end{array}$ & \\
\hline \multirow{2}{*}{$\begin{array}{l}\text { Anti- } \\
\text { T.cruzi }\end{array}$} & & 13.1 & \multirow[t]{2}{*}{1.0} & 16.6 & 0 & \multirow[t]{2}{*}{-} \\
\hline & $(1.6-47.8)$ & $(4.8-28.5)$ & & $(7.1-32.6)$ & - & \\
\hline \multirow[t]{2}{*}{ HTLV } & 0 & 21.8 & \multirow[t]{2}{*}{ - } & 18.3 & 2.9 & \multirow[t]{2}{*}{6.3} \\
\hline & $(-)$ & $(10.5-40.2)$ & & $(8.5-35.4)$ & $(0.7-16.4)$ & \\
\hline \multicolumn{7}{|c|}{${ }^{\mathrm{a}}$ Confidence interval } \\
\hline \multicolumn{7}{|c|}{$\begin{array}{l}\text { b Prevalence ratio using the seroprevalence of donors who did not direct their } \\
\text { donation to a specific recipient as the reference category }\end{array}$} \\
\hline
\end{tabular}

In terms of geographical variation, it is worth stressing very high seroprevalence of hepatitis B markers in the Far West region: $7.0 \%$ for anti-HBc and $0.5 \%$ for HBsAg (Figure 1). The latter figure indicates high transmission rate of hepatitis B infection in 2010 even among blood donors. The highest prevalence of hepatitis C was observed for the Southern and Mountain Highland regions, whereas that of HIV reached its peak of 124.7 per 100.000 in the Midwest region. The Midwest and Mountain Highland regions had the highest seroprevalence of HTLV, while the Itajaí valley and the Mountain Highland region registered the highest risk of T. cruzi infection. 

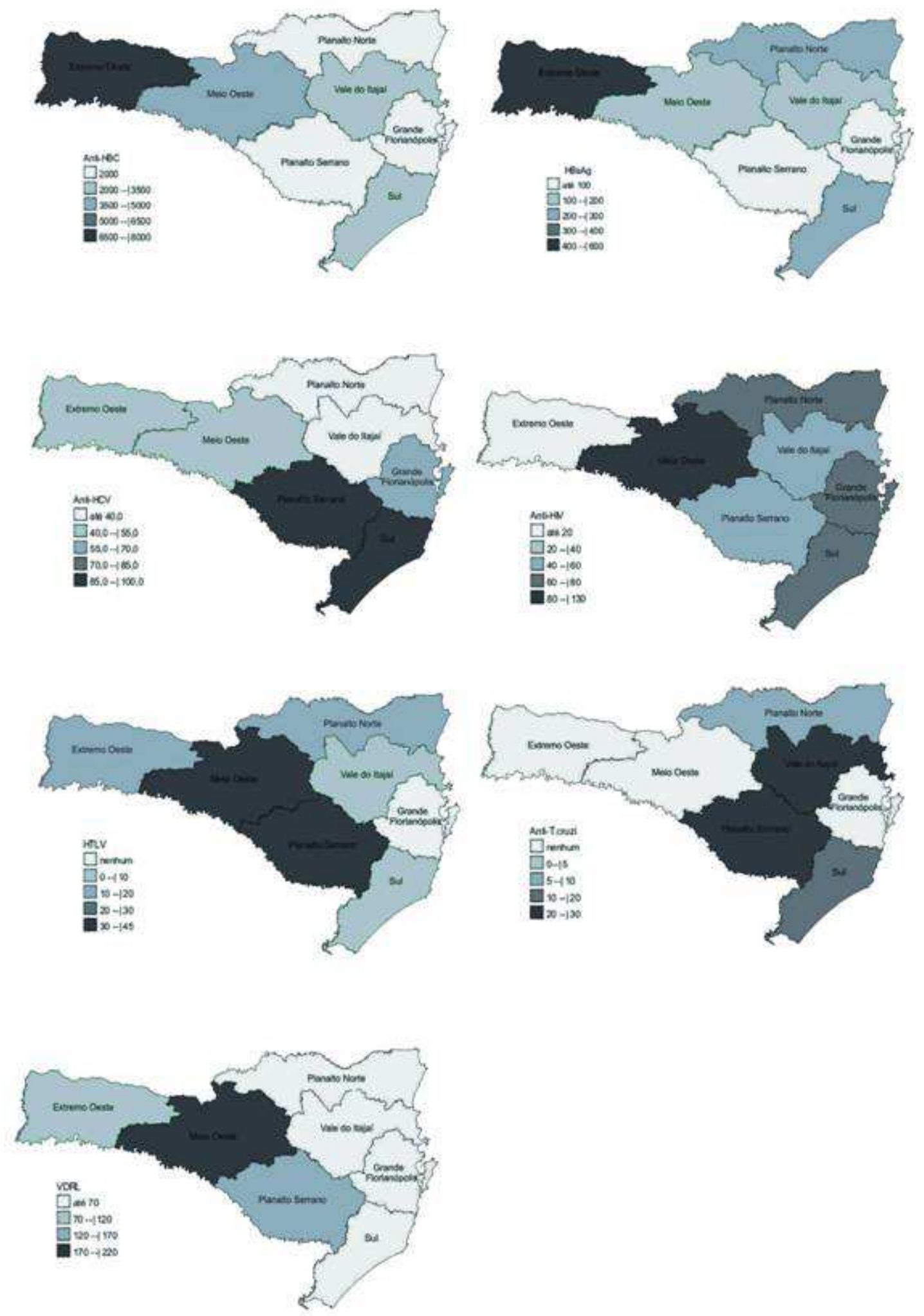

Figure 1. Prevalence of Serologic Markers per 100.000 in Blood Donor Candidates in Santa Catarina, 2010 


\section{Discussion}

The $1.3 \%$ of the population who offered to donate blood in Santa Catarina in 2010 was below the $3 \%$ recommended by the WHO (2010) and the $2.1 \%$ reported by the Brazilian Ministry of Health (2008). This calls for immediate actions to increase the recruitment of new blood donors in order to meet the rising need for blood and its derivatives for medical treatment. Although Silva et al. (2013) results from a population surveys in the state capital Florianopolis showed $6.2 \%$ of the adults reporting a blood donation within the last 12 months, the blood bank data suggest this was an overestimate, possibly due to the survey respondents' inclusion of blood work as a blood donation. Similarly high figures of $7.7 \%$ were published by Zago et al. (2010) for another population survey in the southern city of Pelotas.

Various studies in Brazil reported predominance of male blood donors in the range of $64 \%$ to $76 \%$ (Silva et al. in 2006, Brazilian Ministry of Health in 2008, Brenner et al. in 2008), similar to $57.8 \%$ found in the present study. However, Rosini et al. (2003) found higher proportion of female donors in the western regions of the Santa Catarina state, possibly because of a high deferral rate for the men in this region endemic for hepatitis B.

Higher prevalence of hepatitis B and HIV infection among men in the present study goes along with a multicentric study results by Silveira et al. (1999) who found a significant difference in anti-HBc in the same direction in Brazil but not in other countries. However, other studies such as that by Nascimento (2008) and Brazilian Ministry of Health (2009) did not replicate such findings for anti-HBc or for HIV in the state of Sergipe. Nevertheless, present study found consistently elevated seroprevalence for sexually transmitted diseases in men compared to women.

Brazilian Ministry of Health (2011) also found predominance of male and young blood donors, as well as a reduction of the frequency of blood donation with age. Other studies by Brazilian Ministry of
Health (2006) and Silva et al. (2006) observed that the time of exposure for hepatitis B increases with age, resulting in higher seroprevalence in older age groups. In the beginning of this century, Rosini et al. (2003) showed that the HBsAg marker of a recent hepatitis $B$ infection was more prevalent among older blood donors in Santa Catarina, probably reflecting longer exposure time and absence of universal child vaccination against hepatitis B for this group.

Present study found approximately three quarters of blood donations not directed to a specific recipient, which is within the 50$90 \%$ range reported for Brazil in 2007 by Chávez et al. (2003) in Santa Catarina, Araújo et al. (2010) in the north-eastern city of Recife and Ramos and Ferraz (2010) in the state of Paraná. The studies also showed significantly lower seroprevalence of infectious diseases in this segment of the blood donor population and thus reinforced the importance of a systematic increase of their participation in blood supply.

Predominance of blood donors without previous donation in the last year is also in accordance with other Brazilian sources such as Garcia et al. (2009) and the Ministry of Health (2011). Kupek and Petry (2011) showed huge increase of 15 to 33 times in hepatitis B and hepatitis C markers in this group compared to the repeat donor, thus stressing the need to increase the percentage of the latter on a more permanent basis. Brazilian Ministry of Health (2011) has already observed significant increase in the seroprevalence of infectious disease markers in the first time donors.

The highest hepatitis B prevalence in Brazil during the 2002-2009 period was reported for its southern states, varying from 7.6 to 15.6 per 100.000 , with Santa Catarina reaching anti-HBc prevalence of 48.5 per 100.000 (Ministry of Health, 2010b). However, the present study seroprevalence of $3 \%$ for the same marker in 2010 shows the magnitude of its underestimation by epidemiologic surveillance, keeping in mind that blood donors likely provide a 
lower bound of the true estimate, due to the lower risk of hepatitis $B$ infection among blood donors after clinical and predonation interview screening. In addition, Rosini et al. (2003) reported that the western region of the state showed lower prevalence of hepatitis B markers by the end of the decade 2000 compared to its beginning, suggesting improved effectiveness of blood donor screening.

Although WHO (2010a) estimated hepatitis C prevalence at $2.6 \%$ for the Brazilian general population in the beginning of the decade 2000, Brazilian Ministry of Health found much lower figures, such as $0.31 \%$ for the whole country, close to the Rosini et al. (2003) estimate of $0.34 \%$ for Santa Catarina and that of $0,51 \%$ by Kupek (2001) for its capital. The difference in seroprevalence suggests the effectiveness of the donor screening. Another point worth noticing is that both the present study and epidemiologic surveillance showed the highest hepatitis C seroprevalence in the southern region of the state in 2010, differently from the beginning of the decade 2000 when the Itajaí Valley topped the ranking, as reported by Rosini et al. (2003).

In 2009, Brazilian Ministry of Health (2010c) reported the AIDS incidence per 100.000 per year was estimated of 20.1 in Brazil and 33.1 in Santa Catarina. In the first half of the decade 2000, Spada et al. (2005) found the HIV prevalence in blood donors varying between $0.02 \%$ in the Mountain Highland region and 0.04\% reported by Kupek (2004) in Florianópolis. Present study indicates a significant reduction of average HIV prevalence in blood donor population to $0.006 \%$, with the range between $0.001 \%$ to $0.01 \%$. Midwest and Itajaí Valley were the regions with the highest prevalence. Brazilian Ministry of Health (2010c) reported that the latter had two cities with the highest AIDS incidence in the general population in Brazil.

As for the prevalence of VDRL, HTLV and T. cruzi, most of the studies from other Brazilian blood banks showed more elevated figures (Ferreira et al., 2006;
Dourado et al., 2003; Sobreira et al., 2001; Melo et al., 2009; Moraes-Souza et al., 2006; Martins et al., 2009).

From an international perspective, the prevalence of infectious disese markers found in the present study is much higher than in the developed countries but within the range reported for the developing countries. While it is beyond the scope of this paper to make coutry-wise comparisons for the seven serological markers analyzed here, some examples may illustrate the point. A recent review of HIV incidence and prevalence worldwide found huge variations of prevalence per 100.000 blood donors: 0.2 in Oceania, 1.1 in Central and Northern Europe, 6.6 in Mediterrenean Europe, 17.4 in Southeast Asia and 151.4 in South Africa (Bruhn et al., 2012). No data were provided for the South America in this report. The most recent estimate for the Southeastern and Northeastern regions of Brazil in 20072008 was 92.2 per 100.000 the first time blood donors (Sabino et al. 2012). These figures are considerably higher than the USA HIV prevalence per 100.000 blood donors of 2.9 in 2010 (Dorsey et al., 2013) and 4.0 in 2008 (Zou et al., 2012).

Among present study limitations, it is worth noticing that approximately one in ten donors did not provide complete information on residence. Furthermore, extrapolation of the confirmation rate for screen-positive donors who responded to the invitation for additional serological tests to those who did not is based on an unverified assumption that both groups had the same seroprevalence. Although such adjustment is regularly applied in vital statistics (e.g. for undetermined causes of death), it does not eliminate possible bias completely and certainly underestimates the seroprevalence variability in the population. Also, omitting the zip code, fully or partially, resulted in about $10 \%$ loss of the residence information. Although these donors were kept in statistical analysis as a special group to reduce the chances of selection bias, this information is in principle retrievable with some additional clerical effort. Furthermore, no attempts were 
made to estimate the seroconversion incidence in repeat donors as in residual risk studies in transfusion medicine.

The strengths of the study are nearly $100 \%$ coverage of the blood donor population in the state and the use of self-reported zip code instead of blood bank location to determine the region of residence. Although the latter method is widely used, the two locations do not always coincide. In addition, statistical adjustment for noncompliance with further testing procedures to confirm or reject screen-positive test results reduced the verification bias that would have occurred otherwise.

Based on the present study results, some practical recommendations may be in place. First, hepatitis B infection ever was the most frequent reason for serological deferral of blood donors yet this is a vaccine-preventable disease. Despite universal child immunization against this infection started over two decades ago, its beneficial effects have started to emerge only in the last few years and very gradually as the vacinees are recruited for blood donation. Although the health authorities agree that hepatitis B vaccine should be offered to all blood donors and donor candidates, this opportunity has been largely missed so far. In addition, syphilis prevention and treatment require only modest resources and certainly can be improved within existing strategies for prevention of sexually transmitted diseases.

In conclusion, high prevalence of hepatitis B markers remains the foremost serological criterion for deferral of blood donations in Santa Catarina, followed by other sexually transmitted diseases, such as syphilis and HIV, as well as hepatitis C. The first time donors, male sex and older age all elevated the risk of most transfusion-transmitted infection. Based on the blood donor data as a lower bound for the disease prevalence in the general population, there is a strong evidence of elevated prevalence of HIV in comparison with the Brazilian national average and between 10 and 100 times higher prevalence in comparison with the developed countries.

\section{Acknowledgement}

The author would like to thank Suélen dos Santos Sariva and all HEMOSC staff who helped compiling the data, as well as the blood donors for their cooperation.

\section{References}

Almeida-Neto, C., Sabino, E. C., Liu, J., Blatyta, P. F., Mendrone, A. Junior, Salles, N. A., Leão, S. C., Wright, D. J., Basques, F. V., Ferreira, J. E., Busch, M. P. Murphy, E. L. \& NHLBI Retrovirus Epidemiology Donor Study-II (REDS-II) International Component, Brazil. (2013). "Prevalence of Serologic Markers for Hepatitis B and C Viruses in Brazilian Blood Donors and Incidence and Residual Risk of Transfusion Transmission of Hepatitis C Virus," Transfusion, 53 (4) 827-834.

Andrade, A. L., Martelli, C. M. T., Pinheiro, E. D., Santana, C. L., Borges, F. P. \& Zicker, F. (1989). "Rastreamento Sorológico para Doenças Infecciosas em Banco de Sangue Como Indicador de Morbidade Populacional," Revista de Saúde Pública, 23 (1) 20-25.

Araújo, F. M. R., Feliciano, K. V. O., Mendes, M. F. M. \& Figueiroa, J. N. (2010). "Doadores de Sangue de Primeira Vez e Comportamento de Retorno no Hemocentro Público do Recife," Revista Brasileira de Hematologia e Hemoterapia, 32 (5) 384-390.

Baião, A. M., Kupek, E. \& Petry, A. (2014). "Syphilis Seroprevalence Estimates of Santa Catarina Blood Donors in 2010," Revista da Sociedade Brasileira de Medicina Tropical 47(2).

Brazilian Ministry of Health. (2006). 'Agencia Nacional de Vigilância Sanitária. Pesquisa Revela Perfil de Doadores e NãoDoadores de Sanguem,' Ministério da Saúde, Brasília. Available via http://www.anvisa.gov.br/DIVULGA/NOTI CIAS/2006/ 110106_1.htm [Accessed 13 March 2009]. 
Brazilian Ministry of Health. (2008). 'Saúde, Brasil - Duas Décadas de Transformação Social: Em Constante Aperfeiçoamento o Sistema Único de Saúde Proporciona Atenção Integral Aos Brasileiros,' Ministério da Saúde, Brasília.

Brazilian Ministry of Health. (2009). "Caderno de Informação Sangue e Hemoderivados: Rede Física, Serviços de Hemoterapia, Produção Hemoterápica, Matriz de Indicadores," Ministério da Saúde, Brasília.

Brazilian Ministry of Health. (2010a). 'Secretaria de Vigilância em Saúde Departamento de DST, Aids e Hepatites Virais - Boletim Epidemiológico - Hepatites Virais -' Brasília: Ministério da Saúde, 2010.

Brazilian Ministry of Health. (2010b). Departamento de DST-AIDS. "Hepatites Virais: Desafios Para o Período de 2011 a 2012," Ministério da Saúde, Brasília.

Brazilian Ministry of Health. (2010c). 'Boletim Epidemiológico AIDS-DST: 26 $\underline{\mathrm{a}}$ a 52 a Semanas Epidemiológicas - Julho a Dezembro de 2009; 01a a 26 a Semanas Epidemiológicas - Janeiro a Junho de 2010,' Ministério da Saúde, Brasília.

Brazilian Ministry of Health. (2011). 'Sistema de Notificação de Agravos de Notificação - SINAN,' Ministério da Saúde, Brasília.

Brener, S., Caiaffa, W. T., Sakura, E. \& Proietti, F. A. (2008). "Fatores Associados à Aptidão Clínica Para a Doação de Sangue Determinantes Demográficos e SócioEconômicos," Revista Brasileira de hematologia e hemoterapia, 30 (2) 108113.

Bruhn, R., Lelie, N., Custer, B., Busch, M., Kleinman, S. \& International NAT Study Group. (2013). "Prevalence of Human Immunodeficiency Virus RNA and Antibody in First-Time, Lapsed, and Repeat Blood Donations across Five International Regions and Relative Efficacy of Alternative Screening Scenarios," Transfusion, 53(10 Pt 2) 2399-2412.
Chávez, J. H., Campana, S. G. \& Haas, P. (2003). "Panorama da Hepatite B no Brasil e no Estado de Santa Catarina," Revista Panamericana de Salud Publica, 14 (2) 9196.

Dorsey, K. A., Moritz, E. D., Steele, W. R., Eder, A. F. \& Stramer, S. L. (2013). "A Comparison of Human Immunodeficiency Virus, Hepatitis C Virus, Hepatitis B Virus, and Human T-Lymphotropic Virus Marker Rates for Directed versus Volunteer Blood Donations to the American Red Cross during 2005 to 2010," Transfusion, 53 (6) 1250-1256.

Dourado, I., Alcantara, L. C. J., Barreto, M. L., Teixeira, M. G. \& Galvão-Castro, B. (2003). "HTLV-I in the General Population of Salvador, Brazil," Journal of Acquired Immune Deficiency Syndrome, 34 (5) 527531.

Ferreira, C. M., Ferreira, W. A., Motta, C. L., Vasquez, F. G. \& Pinto, A. F. (2006). "Reatividade do Teste VDRL em Bolsas de Sangue da Fundação de Hematologia e Hemoterapia do Amazonas-HEMOAM, os Custos Decorrentes do Descarte e a Estimativa de Prevalência de Sífilis em Doadores de Sangue do Estado do Amazonas," Jornal Brasileiro das Doenças Sexualmente Transmissíveis, 18 (1) 14-21.

Garcia, F. B., Pereira, G. A., Martins, P. R. J. \& Moraes-Souza, H. (2009). "Epidemiological Profile of Hepatitis C in Blood Donors at the Uberaba Regional Blood Center," Revista da Sociedade Brasileira da Medicina Tropical, 42 (1) 1-4.

Glynn, S. A., Kleinman, S. H., Schreiber, G. B., Busch, M. P., Wright, D. J., Smith, J. W., Nass, C. C. \& Williams, A. E. (2000). "Trends in Incidence and Prevalence of Major Transfusion-Transmissible Viral Infections in US Blood Donors, 1991 to 1996," JAMA, 284 (2) 29-35.

Jilg, W., Hottenträger, B., Weinberger, K., Schlottmann, K., Frick, E., Holstege, A., Schölmerich, J. \& Palitzsch, K. D. (2001). "Prevalence of Markers of Hepatitis B in the Adult German Population," Journal of Medical Virology, 63 (2) 96-102. 
Kupek, E. (2004). "Residual Transfusion Risk for HIV and Hepatitis B and C," Brazilian Journal of Infectious Diseases, 8 (3) 236-240.

Kupek, E. J. (2001). "Residual Transfusion Risk for Hepatitis B and C in Southern Brazil, 1991-1999," Journal of Viral Hepatitis, 8 (1) 78-82.

Kupek, E. \& Petry, A. (2011). “Comparison of Epidemiological Methods for Estimation of Hepatitis B Incidence and Residual Risk for Blood Donors in Southern Brazil," Journal of Transfusion, (2011) 1-8.

Maresch, C., Schluter, P. J., Wilson, A. D. \& Sleigh, A. (2008). "Residual Infectious Disease Risk in Screened Blood Transfusion from a High-Prevalence Population: Santa Catarina, Brazil," Transfusion, 48 (2) 273281.

Martins, P. R. J., Martins, R. A., MoraesSouza, H., Barbosa, V. F., Pereira, G. A., José M. J. Eustáquio, J. M. J. \& Lima, G. M. (2009). "Perfil do Doador de Sangue Autoexcluído no Hemocentro Regional de Uberaba-MG (HRU) no Período de 1996 a 2006," Revista Brasileira de Hematologia e Hemoterapia, 31 (4) 222-227.

Melo, A. S., Lorena, V. M. B., Moraes, A. B., Pinto, M. B. A., Leão, S. C., Soares, A. K. A., Gadelha, M. F. S. \& Gomes, Y. M. (2009). "Prevalência de Infecção Chagásica em Doadores de Sangue no Estado de Pernambuco, Brasil," Revista Brasileira de Hematologia e Hemoterapia, 31 (2) 69-73.

Moraes-Souza, H., Martins, P. R. J., Pereira, G. A., Ferreira-Silva, M. M. \& Abud, M. B. (2006). "Perfil Sorológico para Doença de Chagas dos Doadores de Sangue do Hemocentro Regional de Uberaba," Revista Brasileira de Hematologia e Hemoterapia, 28 (2) 110-114.

Nascimento, M. C., Mayaud, P., Sabino, E. C., Torres, K. L. \& Franceschi, S. (2008). "Prevalence of Hepatitis B and C Serological Markers among First-Time Blood Donors in Brazil: A Multi-Center Serosurvey," Journal of Medical Virology, 80 (1) 53-57.
Ramos, V. F. \& Ferraz, F. N. (2010). "Perfil Epidemiológico dos Doadores de Sangue do Hemonúcleo de Campo Mourão-PR no ano de 2008," SaBios: Revista de Saúde e Biologia, 5 (2) 14-21.

Rosini, N., Mousse, D., Spada, C. \& Treitinger, A. (2003). "Seroprevalence of HbsAg, Anti-HBc and Anti-HCV in Southern Brazil, 1999-2001," Brazilian Journal of Infectious Diseases, 7 (4) 262-267.

Santos, E. A. S., Marcellini, P. S. \& Ribeiro, J. P. (2008). "Avaliação Epidemiológica das Rejeições dos Doadores de Sangue no HEMOLACEN/SE no Período de 2004 a 2006," Revista Brasileira de Análises Clínicas, 40 (4) 251-256.

Silva, R. M. G., Kupek, E. \& Peres, K. G. (2013). "Prevalência de Doação de Sangue e Fatores Associados em Florianópolis: Estudo de Base Populacional no Sul do Brasil," Cadernos de Saúde Pública, 29 (10) 2008-2016.

Silva, R. S. U., Ribeiro, S. A. L., Silveira, R. P. \& Freitas, M. S. (2006). "Avaliação da PréTriagem Sorológica para o Marcador do Vírus da Hepatite B (anti-HBc total) em Candidatos à Doação de Sangue no Estado do Acre, 2002," Revista da Sociedade Brasileira da Medicina Tropical, 39 (2) 179182.

Silveira, T. R., Fonseca, J. C., Rivera, L., Fay, O. H., Tapia, R., Santos, J. I., Urdeneta, E. \& Clemens, S. A. C. (1999). "Hepatitis B Seroprevalence in Latin América," Revista Panamericana de Salud Publica, 6 (6) 378383.

Sobreira, A. C. M., Gomes, F. V. B. A. F., Silva, M. A. M. \& Oliveira, M. F. (2001). "Prevalência de Infecção Chagásica em Doadores de Sangue do Hemocentro Regional de Iguatu, CE," Revista da Sociedade Brasileira da Medicina Tropical, 34 (2) 193-196.

Spada, C., Souza, M. A. \& Treitinger, A. (2005). "Estimation of the Residual Risk for the Transmission of HIV in Blood Donors from the Mountain Region of Santa 
Catarina," Brazilian Journal of Infectious Diseases, 9 (6) 489-493.

StataCorp. Stata Statistical Software: Release 9. (2005). Stata Corp LP, College Station, Texas, USA.

WHO - World Health Organization. (2010a). Screening Donated Blood for Transfusion-Transmissible Infections: Recommendations, World Health Organization, Geneva.

WHO - World Health Organization. (2010b). "Towards 100\% Voluntary Blood Donation: A Global Framework for Action," World Health Organization, Geneva, Switzerland.
Zago, A., Silveira, M. F. \& Dumith, S. C. (2010). "Prevalência de Doação de Sangue e Fatores Associados, Pelotas, RS," Revista de Saúde Pública, 44 (1) 112-20.

Zou, S., Stramer, S. L. \& Dodd, R. Y. (2012). "Donor Testing and Risk: Current Prevalence, Incidence, and Residual Risk of Transfusion-Transmissible Agents in US Allogeneic Donations," Transfusion Medicine Reviews, 26(2) 119-12. 